\title{
Influence of Raters' Attributes on Biases Toward Immigrants
}

\author{
Kimberly M. Lukaszewski \\ Wright State University \\ Dianna Contreras Krueger \\ Tarleton State University \\ Dianna L. Stone \\ Universities of New Mexico, Albany, and Virginia Tech \\ Julio C. Canedo \\ University of Houston Downtown
}

\begin{abstract}
Although immigrants offer many benefits for organizations and our society, they continue to experience unfair discrimination, prejudice, and hostility in the employment process. One contributing factor towards the negative perceptions toward immigrants are the raters' attributes (i.e., decision makers in the workplace). These attributes include their demographic background (e.g., age, gender), differences between raters' and immigrants' cultural values, raters' personality, and raters' previous contact with immigrants. In order to understand raters' biases toward immigrants, we used the social cognition framework (Miller \& Brewer, 1984) to explain the reasons for these biases, and offered hypotheses to guide future research on the issue.
\end{abstract}

Keywords: Immigrants, Biases, Unfair Discrimination

\section{INTRODUCTION}

Currently, a great divide exists among Americans regarding immigration. Some Americans view immigrants as advantageous to the country because they bring unique skills and innovative approaches to problems, but others view all immigrants as illegal persons who burden the country and take advantage of social service systems. However, most Americans do not realize that the majority of immigrants in the United States (U. S.) are legally authorized to be here (Gramlich, 2019). In fact, recent research estimates that $75 \%$ of immigrants living in the U. S. are authorized to be in this country (Pew Research, 2018). According to the Bureau of Labor and Statistics (2018), immigrants are often employed in jobs that citizens would not do or even call undesirable. These jobs are found in the areas of agriculture, production, construction, and materials maintenance. Although most citizens would not take on such jobs, 
over seventy percent still make the claim that undocumented immigrants take jobs their jobs and decrease wage rates (Pew Research, 2018).

Despite the negative views of immigrants, they offer numerous benefits to companies and society as a whole. One reason for this is that there has been a decline in the population in the U. S. and other Western nations, and some industries (e.g., high tech, chemistry, agriculture) cannot find employees to fill critical vacancies. Thus, some researchers estimate the U. S. will benefit greatly from increased numbers of immigrants that will enhance the skill levels of the workforce, increase innovation and creativity, and fill job openings (Friedman, 2010). Regardless of the many advantages they offer organizations, immigrants continue to face unfair discrimination, prejudice, and even hostility in the workplace in the U. S. and other nations (Dietz, 2010).

Several factors contribute to the differentiation of views about immigration including rater characteristics, attributes of the immigrant, and the nature of jobs. For instance, research has shown that raters with low educational levels are more likely to resent immigrants than those with high educational levels because they view them as competitors (Scheve \& Slaughter, 2001; Wilkes, Guppy, \& Farris, 2008). Furthermore, negative perceptions about immigrants may be a function of a variety of other factors including raters' age, gender, education and skill levels, socioeconomic status, cultural values, country of origin, religious values, personality, and previous contact with immigrants.

As a consequence of these negative perceptions, immigrants often face exclusion, low wage levels, and assignment to low level jobs in the workplace. It merits noting that some research has examined the attributes of immigrants that affect negative reactions to them in the workplace (Stone, Lukaszewski, Krueger, \& Canedo, 2019), but we know of no reviews research that have specifically focused on the attributes of raters that affect biases toward immigrants. Thus, the primary purposes of this paper are to (a) consider a number of rater attributes that negatively affect reactions to immigrants and unfair discrimination against them, (b) review the existing research on these issues, and (c) offer hypotheses to foster additional research and practice on this important topic. For example, we consider the relations between raters' demographic characteristics (e.g., age, and gender), cultural values, country of origin, religious values, personality, prejudice against immigrants, and previous contact with immigrants related to biases toward immigrants. We define unfair discrimination as "unfair behavioral biases against immigrants based on their group, social identity, stigma, category and ascribed characteristics" (Dipboye \& Colella, 2005, p. 2).

For the remainder of this paper, we refer to immigrants as individuals who migrate to another country, usually for permanent residence, and are in the host country legally (Dietz, 2010).

\section{ATTRIBUTES OF RATERS THAT AFFECT BIAS TOWARD IMMIGRANTS}

The social cognition model (Miller \& Brewer, 1984) explains reactions to immigrants in organizational settings. This model suggests that when raters (i.e., organizational decision makers) encounter immigrants (e.g., who have applied for a job or promotion) they assign the person to a category. For instance, they may categorize the person as a Latin American immigrant, and the categorization evokes stereotypes about the person that may include unintelligent, lazy, uneducated, or untrustworthy criminals (Timberlake \& Williams, 2012). Stereotypes are defined as "a set of beliefs about the personal attributes of a group of people" (Ashmore \& Del Boca 1981, p1). Stereotypes then result in job expectancies which are anticipatory beliefs about the degree to which the immigrant will be successful on the job. For example, if raters feel uncomfortable with the immigrant job applicants and believe that they are lazy or unintelligent, then they are likely to expect that their job performance will would be poor. In the following sections, we consider a number of raters' attributes that may cause them to assign immigrants to a negative category and stereotype them unfavorably. We also review the existing research on these rater attributes, and offer hypotheses and suggestions to foster research on the topic.

Several attributes of raters are likely to influence how immigrants are categorized, stereotyped, and have a negative impact on decisions made about them. Specifically, we believe that demographic characteristics, cultural values, country of origin, religious values, personality, prejudice against 
immigrants and previous contact with immigrants will likely influence job expectancies and employment decisions made about immigrants. These attributes are considered below.

\section{RATERS' CHARACTERISTICS}

There are several demographic characteristics of raters (e.g., gender, education and skill level) that are likely to influence how immigrants are categorized and stereotyped, which will likely have a negative effect on job expectancies and employment decisions made about them. We consider these demographic characteristics in the paragraphs that follow.

\section{Gender}

We believe that gender of the raters is likely to affect the categorization, stereotyping, and job-related expectancies and decisions made about immigrants. Given the difference in the way men and women are socialized, we believe that women are likely to have more positive attitudes toward immigrants than men. Specifically, researchers have concluded that women are socialized to be more other-focused, sympathetic, agreeable, and nurturant than men (Feingold, 1994; Pettigrew \& Tropp, 2006). Therefore, women are more likely to interact with people in the community, which is likely to facilitate proimmigrant attitudes. In addition, when women are well educated, they are more likely than men to understand social relations, and gain a greater ability to appreciate cultural differences and similarities (Hughes \& Tuch, 2003). This appreciation of cultural differences, referred to as cultural intelligence by some researchers (Ang et al., 2007), is likely to be positively related to attitudes regarding immigrants. Results from research by Facchini and Mayda (2006) also support this argument. They found that in Sweden and Western Europe, although boys and girls did not differ in respect to classical racism, but boys did score higher on modern racism and prejudice toward immigrants than girls. Results of a survey by Amuedo-Dorantes and Pozo (2006) indicated that more women wanted to continue legal immigration in the U. S. than men. These differences may be attributed to men scoring higher in social dominance than women (Lippa, 2005). Finally, results of research by Berg (2010) indicated that women were less likely to believe that immigrants take jobs away from native-born Americans than men, and educated women were more likely to express pro-immigrant attitudes relative to educated men. Therefore, we propose the following hypothesis.

H1: Women will be more likely to (a) assign immigrants to a positive category, (b) stereotype them favorably, and have more positive (c) job expectancies, and make more positive (d) job related decisions about immigrants than men.

\section{Education and Skill Levels}

We also believe that the education and skill levels of the rater will 1 influence how immigrants are categorized and stereotyped, and stereotypes will have a negative effect on job expectancies and employment decisions. Specifically, we believe that raters with high levels of education and skills will have more positive attitudes regarding immigrants than those with low levels of education or skills. Our rationale for this is that individuals with high levels of education and skills may be less likely to perceive that immigrants will take their jobs than those with low educational levels. In addition, educational level is frequently associated with greater tolerance toward outgroup members (Chandler \& Tsai, 2001). Consistent with these arguments, results of research by Chandler and Tsai (2001) revealed that level of education was negatively related to anti-immigrant attitudes, and raters with low skill levels and an elementary level education were more likely to prefer limiting immigrants into the U. S. (Scheve \& Slaughter, 2001; Wilkes et al., 2008). Furthermore, results of research indicated that tolerance for immigrants is higher for those individuals who are more educated, older, and live in metropolitan rather than rural areas (Cote, \& Erickson, 2009). Similarly, results found that low and high skilled raters preferred immigrants with high rather than low skill levels (Hainmueller \& Hiscox, 2010). Thus, we propose the following hypothesis. 
H2: Raters with low levels of education and skills will be more likely to (a) assign immigrants to a more negative category, (b) stereotype them unfavorably, and (c) assign negative job expectancies, and (d) make negative job related decisions about immigrants than those with high levels of education.

\section{Socioeconomic Status}

We believe that socioeconomic status (SES) of the raters will be related to how immigrants are categorized, stereotyped, and treated in organizational settings. The main reason for this belief is that individuals with low levels of income should be more likely to perceive that they are competing for jobs and resources with immigrants than those with high levels of income. As a result, raters with low SES will be more likely to categorize and stereotype immigrants more negatively than their high SES counterparts. In spite of these arguments, results of research regarding SES of raters and attitudes toward immigrants are somewhat inconsistent.

First, results of research in Germany by Becchetti, Rossetti, and Castriota (2010) revealed that personal income was negatively related to self-declared concern about immigrants. Furthermore, when an individuals' income was reduced by $2.28 \%$ their concern about immigrants increased, but when their income increased by $1.83 \%$ their concern about immigrants decreased (Becchetti et al., 2010). Further, individuals who were unemployed or experienced high inflation rates were more likely to have concerns regarding immigrants than those who were employed or received a rise in income levels (Becchetti et al., 2010).

Results of other research by Jetten, Mols and Postmes (2015) in Switzerland and Australia found more anti-immigrant attitudes among those with relatively low and high income levels than those with moderate income levels. Results of another study revealed that when inequality was increasing in a society, members of all levels of income were more opposed to immigrants than when inequality was decreasing (Jetten et al., 2015). Thus, it appears that concern about future income levels is likely to influence attitudes toward immigrants. We propose the following hypothesis.

H3: Socioeconomic status of the rater will be negatively related to the (a) categorization (b) stereotyping, and (c) job expectancies of immigrants, and (d) job related decisions about immigrants.

\section{Country of Origin}

The rater's country of origin is likely to influence the categorization, stereotyping, and job-related decisions made about immigrants. People in a country establish consensual stereotypes about members of an outgroup, and these stereotypes are made salient by peers, teachers, parents, the media, and political leaders (Stangor, 2000).

Theory and research on social identity argue that people are motivated to enhance their self-esteem and distinguish their group from other groups by demeaning or attributing negative stereotypes to other group members in order to enhance the standing of their own group (Brown, 1995; Tajfel \& Turner, 1979). Consensual stereotypes are harmful because they have a negative impact on an entire group of people (e.g., immigrants) (Gardner, 1973). For example, the consensual stereotypes of U. S. citizens may cause raters to view immigrants as lazy and unintelligent so that they will have a higher social standing than immigrants. They may also argue that immigrants take their jobs and accept lower wage rates in order to disparage them and increase their own self-esteem.

This process of categorization and stereotyping can be further explained by applying the Stigma Model (Stone, Stone, \& Dipboye, 1992). It predicts that when raters meet an individual for the first time, they frequently assign them to a category (e.g., unintelligent, lazy, uneducated, or untrustworthy, criminals). Then they use a membership category to stigmatize the person. A stigma is a deeply discrediting characteristic. For example, if a person is categorized as a Mexican immigrant, then the rater may stigmatize them as an unintelligent, lazy, criminal. Although these stereotypes are not accurate, the rater (i.e., decision maker in organizations) uses them to develop expectancies or anticipatory beliefs about the individuals' potential job performance. These expectancies are likely to have a negative impact on job related decisions made about the individual (e.g., individual is not selected for the job). More 
succinctly, if raters stigmatize the immigrant as lazy, then they are likely to give the person low jobrelated ratings and will be unlikely to hire them for a job.

We know of no specific research that has examined the extent to which national consensual stereotypes or stigmas influence job expectancies and employment decisions about immigrants. As a result, we offer the following hypothesis to guide research.

H4: Raters' negative consensual stereotypes of immigrants will have a negative impact on (a) the categorization of immigrants, (b) job related expectancies, (c) job ratings, and (d) job-related decisions about them.

Age

We believe that raters' age will influence the categorization, and stereotyping of immigrants and jobrelated decisions made about them. Specifically, people may perceive that as they get older they are less able to compete with immigrants for jobs than younger individuals. Therefore, age should negatively relate to attitudes regarding immigrants. There is some research on age differences in attitudes regarding immigrants, but it does show support for our argument (e.g., Becchetti et al., 2010). Research in Germany found that age was positively related to concern about immigrants joining a society (Becchetti et al., 2010). However, research by Cote and Erikson (2009) found the opposite effects. Their results revealed that age was positively related to tolerance toward immigrants. Thus, the relation between raters' age and attitudes toward immigrants is not exactly clear, and we believe that additional research is needed to examine this relation and the underlying reasons for it. Although the research results are inconsistent, we believe that older raters will be more likely to view immigrants negatively than those who are younger because they have less ability to compete for jobs or other resources. Thus, we proposed the following hypothesis.

H5: The age of the rater will be negatively related to the (a) categorization (b) stereotyping, and (c) job expectancies of immigrants, and (d) job related decisions about them.

\section{Differences in Values}

We believe that differences in values between rater and the immigrant (i.e., cultural values, and religious values) are likely to influence how immigrants are categorized and stereotyped, which is likely have a negative effect on job expectancies and employment decisions made about them. We consider these differences in values in the paragraphs that follow.

\section{Differences in Cultural Values}

Another factor that is likely to affect the categorization, stereotyping, and decision-making about immigrants is the difference between raters' and immigrants' cultural values. According to Stephan and Stephan (1985), people tend to view their own values as morally right, and immigrants with different values are likely to threaten their worldviews. Thus, natives may be concerned that immigrants with different cultural values will not assimilate to the dominant culture and will actually dilute the existing culture. According to Trice and Beyer (1993), the predominant cultural values in the U. S. stress individualism, competitive achievement, egalitarianism, low power distance, autonomy, and an emphasis of work over family. As a result, raters are likely to view immigrants negatively when they do not share or assimilate to these values.

Results of research showed that Latin American immigrants in the U. S. are viewed as having different cultural values (e.g., collective, familistic), and are often viewed more negatively than others. For example, Latin American immigrants are more likely to value collectivism than individualism, and are usually more family oriented than natives in the U. S. Furthermore, they are often viewed as being less likely than others to assimilate to the dominant culture, unwilling to learn English, and may be viewed as perpetual foreigners in their new country (Huynh, Devos, \& Smalarz, 2011; Stephan \& Stephan, 1985). 
Some researchers in Europe also argued that immigrants are often rated more negatively than others because their cultural values differ from the dominant European values (Foner \& Alba, 2008). For instance, some studies in Europe revealed that Muslims were often viewed more negatively than other groups because their cultural values were antithetical to the dominant European values of freedom, autonomy, and gender equality (Foner \& Alba, 2008). Research also showed that immigrants from Ecuador and Romania were viewed more positively than those from Islamic Middle Eastern countries because their cultural values were similar to European values (Stephan, Ybarra, \& Bachman, 1999). Thus, it appears that differences in the cultural values of raters and immigrants are likely to produce negative attitudes of immigrants. Even though these arguments seem plausible, there has been relatively little research on the effects of differences in cultural values on reactions to immigrants. Thus, we propose the following hypothesis.

H6: Differences in cultural values between raters and immigrants will have a negative impact on the (a) categorization, (b) stereotyping, (c) job expectancies about immigrants, and (d) job-related decisions about them.

\section{Differences in Religious Values}

We believe that the religious values of the rater will also impact their views about immigrants. The argument here is similar to the one above regarding similarity of cultural values. Shared religious values between the rater and the immigrant are likely to influence more positive reactions toward immigrants than when the religious values of raters and immigrant are different. Historically, the predominant religion in the U. S. has been Protestant (Smith,1991), and increasing numbers of Hispanics, Middle Eastern, and Asian immigrants threaten these values by bringing different religious views such as Catholicism, Islam, Buddhism, and Hinduism. As noted above, raters typically see their own religious values as being morally correct and are likely to be threatened by these different values (Stephan et al., 1999). Additionally, raters are likely to fear that new religious values will supersede their own values, and they will become the outsider (Stephan \& Stephan, 1985). As a result, raters develop negative and even hostile views towards immigrants who have different religious values.

Results of research have provided some support for this argument. For instance, results of research revealed that members of fundamental Christian religions had more anti-immigration views than others (McDaniel, Nooruddin, \& Shortle, 2011). Similarly, results of other research indicated that evangelical Protestant raters were less tolerant, and had more negative attitudes toward immigrants with different religions (Moore \& Ovadia, 2006). However, results of a study by Knoll (2009) found that individuals who were members of minority religions such as Judaism or the Latter Day Saints religion were more likely to be empathetic and supportive of liberal immigration reform than others. Although there is some research on differences in raters' and immigrants' religious beliefs, we are not aware of research on this topic in employment contexts. Thus, even though there are civil rights laws (Civil Rights Act of 1964; 1991) that preclude discrimination based on religious beliefs, we believe that differences in religious values will have a negative influence employment decision. Therefore, we propose the following hypothesis.

H7: When raters' religious values are different than immigrants' religious values then immigrants will be (a) assigned to a more negative category, (b) stereotyped unfavorably, and will receive more unfavorable (c) job expectancies and (d) employment decisions.

\section{Personality and Previous Contact}

There are several personality characteristics of the rater (e.g., authoritarianism, social dominance, and prejudice toward the immigrant) as well as previous contact between the rater and the immigrant are likely to influence how immigrants are categorized and stereotyped, which will likely have a negative effect on job expectancies and employment decisions made about them. We consider these factors in the paragraphs that follow. 


\section{Authoritarianism and Social Dominance}

We believe that the personality of the raters should also have an impact on their views of immigrants. Previous research indicated that authoritarianism and social dominance orientation are related to prejudicial attitudes toward outgroup members (Pratto, Sidanius, Staffwoth, \& Malle, 1994). For example, Adorno, Frenkel-Brunswick, Levinson, and Sanford (1950) defined authoritarianism as the degree that individuals defer to authority, accept conventional and conservative rules and norms, and show hostility to outsiders who break the norms of society. It should also be noted that right-wing authoritarianism is defined as the willingness to submit to authorities perceive as established and legitimate, adhere to societal conventions and norms, and hostile and punitive attitudes towards people (Altemeyer, 1998). Social dominance orientation refers to the degree an individual wants their in-group to be dominant and superior to out-groups, and the desire to have inequality and hierarchy in social relations (Pratto et al., 1994).

Research has shown that social dominance is linked to several social and political ideologies that are hierarchical such as racism (Pratto et al., 1994). Results of research also revealed a negative relation between authoritarianism and attitudes toward others (Fisher, Deason, Borgida, \& Oyamot, 2011; Oyamot, Borgida, \& Fisher, 2006). In addition, studies indicated that raters who were high in social dominance orientation, political conservatism, and authoritarianism were more likely to view immigrants negatively than their counterparts (Bassett, 2010). Finally, other researchers (Guimond, Olveria, Kamiesjki, \& Sidanius, 2010) showed that individuals in France who were high in inequality and social dominance orientation were more prejudiced regarding immigrants than those low in inequality and social dominance. Although there is some research on this issue in social contexts, we are not aware of any research on these relations in employment situations. Thus, we propose the following hypotheses to guide future research in employment contexts.

H8: Raters with high level of (a) social dominance and (b) authoritarian orientation will negatively (a) categorize (b) stereotype, and provide negative (c) job expectancies of immigrants, and (d) job related decisions about immigrants.

\section{Prejudice Against Immigrants}

Another factor that should affect the categorization, stereotyping and job-related decisions about immigrants is raters' prejudice toward them. Prejudice can be defined as preconceived judgments or negative opinions about a group or its members that is not based on fact or accurate information (Dipboye \& Colella, 2005). Although we tend to think that there is only one type of prejudice, some researchers (Bushwick, 2011) argued that raters express different types of prejudice toward different groups and these prejudices have very different emotional components. For instance, raters may fear or express anger toward immigrants from Islamic Middle Eastern countries because a few fundamentalists from Islamic countries have attacked other countries around the world. Other raters may feel that Latin American immigrants are unfair because they take advantage of social services in their new countries or work for lower wages than natives which may drive wage rates down (Bushwick, 2011). Thus, different types of prejudice are likely to affect raters' categorization, stereotyping and job-related decisions in varying ways.

Research shows that there are a number of underlying reasons that raters are prejudiced toward immigrants (Krings \& Olivares, 2006). For instance, one reason for raters' prejudice is that people may perceive immigrants as threatening because they look different, speak other languages, eat different foods, and are viewed as having contagious diseases (Stephan \& Stephan, 1985). Those immigrants that are thought to be infectious or are viewed as dishonest cheaters are seen as extremely frightening, and these threats activate powerful prejudices among raters (Bushwick, 2011). Other research by Derous Nguyen, and Ryan (2009) revealed that ratings of Muslim applicants were lowest when Dutch raters' implicit prejudice was high, but there were no effects when explicit prejudice was high. Thus, the influence of raters' prejudice on hiring decisions may be very subtle. Implicit prejudice is often defined as negative feelings and/or beliefs about a group that people have without being aware of it (Kinder \& Sears, 1981). 
In contrast, raters who have overt or explicit prejudice express negative beliefs and emotions directly (e.g., denying immigrants jobs or employment opportunities) (Kinder \& Sears, 1981).

Even though there has been some research on different forms of raters' prejudice on evaluations of immigrants, we believe that additional research is needed to understand the relation between varying forms of prejudice (e.g., implicit vs. explicit) and reactions to immigrants in work settings. Thus, we offer the following hypotheses:

H9: Raters who have explicit forms of prejudice will be more likely to (a) assign immigrants to a more negative category, (b) stereotype them more unfavorably, and provide them with (c) more negative job expectancies, and (d) job related decisions than those who have implicit forms of prejudice.

H10: Raters who have implicit forms of prejudice will be more likely to (a) express prejudice indirectly, and (b) oppose organizational policies that stress hiring immigrants than those with explicit forms of prejudice.

\section{Previous Contact with Immigrants}

Research argues that increased positive contact with outgroup members (e.g., immigrants) will have a positive impact on reactions to them (Brewer \& Miller, 1984; Cook, 1978). The rationale here is that positive contact with outgroup members presents raters with individuating information that can be used to disconfirm stereotypes about them (Brewer \& Miller, 1984). In support of these arguments, results from several studies showed that more frequent contact with immigrants was associated with less anxiety and more positive attitudes toward them (e.g., Leong, 2008; Ward \& Masgoret, 2006). Further, results of numerous studies in Italy and Belgium indicated that when raters had contact with immigrants they were likely to have more empathy, less intergroup anxiety, and better attitudes regarding immigrants (Capozza, Trifiletti, Vezzali, \& Favara, 2013; Dhont, Roets, \& Van Hiel, 2011; Pagotto, Voci, \& Maculan, 2010; Vezzali, Giovanni, \& Capozza, 2010; Visintin, Voci, Pagotto, \& Hewstone, 2017; Voci \& Hewstone, 2003). However, it merits emphasis that the contact with immigrants must be positive for attitudes toward them to change (Dixon, 2006; Ha, 2010; Stone \& Colella, 1996; Yuker, 1988). We are not aware of any studies that have examined the relation between positive contact and attitudes toward immigrants in organizations. Therefore, we present the following hypotheses to guide future research.

H11: Raters' positive contact with immigrants will be positively related to the (a) categorization (b) stereotyping, and (c) job expectancies about immigrants, and (d) job related decisions about them.

\section{SUMMARY}

In the sections above, we reviewed the attributes of raters thought to affect unfair discrimination against immigrants. Our review indicated that several attributes of raters are likely to influence the categorization, stereotyping, job expectancies, and job related decisions about immigrants. Specifically, we predict that raters' demographic background (e.g., age and gender), differences in raters' and immigrants' values, the rater's personality (e.g., social dominance orientation, authoritarianism), and previous contact between raters and immigrants are likely to influence biases toward immigrants in the employment contexts. Given raters' biases toward immigrants, they are often given lower salary levels, and assigned to low-level dead-end positions in organizations. One area of research that is encouraging is that positive contact between the rater and immigrant may result in more positive views and job-related decisions about immigrants. Although there has been some research on the relations between raters' attributes and job-related decisions about immigrants, we believe that much more research is needed to identify the attributes of raters that influence employment decisions about immigrants. 


\section{CONCLUSION}

Even though immigrants offer many benefits for organizations and our society, they continue to experience unfair discrimination, prejudice, and hostility in the employment process. As a result, organizations are not utilizing the many skills and advantages that they bring to the workforce, and immigrants are not always experiencing a fulfilling work life. In order to understand raters' biases toward immigrants, we used the social cognition framework (Miller \& Brewer, 1984) to explain the reasons for these biases, and offered hypotheses to guide future research on the issue. We also believe that an understanding of raters' prejudice toward immigrants will help organizations develop training programs, and other interventions that can be used to overcome these problems. Specifically, we believe that negative perceptions toward immigrants are likely a function of variety of raters' attributes including their demographic background (e.g., age, gender), differences between raters' and immigrants' cultural values, raters' personality, and raters' previous contact with immigrants. In view of these biases, organizations may overlook the many advantages that immigrants bring to the workforce (e.g., increased innovation, expanding customer bases), and may not give immigrants a fair opportunity to achieve a satisfying career. We hope that this paper will expand our understanding of the bases for unfair discrimination against immigrants, guide future research on the topic, help organizations utilize the talents and skills that immigrants bring to the workforce, and enable immigrants to enjoy a gratifying work life.

\section{REFERENCES}

Adorno, T. W., Frenkel-Brunswik, E., Levinson, D. J., \& Sanford, R. N. (1950). The authoritarian personality. New York: Harper.

Altemeyer, R. A. (1998). The other "authoritarian personality. In M. P. Zanna (Ed.), Advances in experimental social psychology, 30, 47-91. New York: Academic Press.

Amuedo-Dorantes, C., \& Pozo, S. (2006). Migration, remittances, and male and female employment patterns. American Economic Review, 96(2), 222-226.

Ang, S. Van Dyne, L., Koh, C., Ng, K. Y., Templer, K. J., Tay, C., \& Chandrasekar, N. A. (2007). Cultural intelligence: Its measurement and effects on cultural judgment and decision making, cultural adaptation and task performance. Management and Organization Review, 3(3), 335-371.

Ashmore, R. D., \& Del Boca, F. K. (1981). Conceptual approaches to stereotypes and stereotyping. In D. L. Hamilton (Ed.), Cognitive processes in stereotyping and intergroup behavior (pp. 1-35). Hillsdale, NJ: Erlbaum.

Bassett, J. F. (2010). The effects of mortality salience and social dominance orientation on attitudes toward illegal immigrants. Social Psychology, 41, 52-55.

Becchetti, L., Rossetti, F., \& Castriota, S. (2010). Real household income and attitude toward immigrants: An empirical analysis. The Journal of Socio-Economics, 39, 81-88.

Brewer, M. B., \& Miller. N. (1984). Beyond the contact hypothesis: Theoretical perspectives on desegregation. In N. Miller \& M. Brewer (Eds.), Groups in conflict: A psychology of desegregation (pp. 281-302). San Diego, CA: Academic.

Brown, R. (1995). Prejudice in Social Psychology. Malden, MA: Blackwell Publishing

Bureau of Labor Statistics. (2018). Foreign-born workers: Labor characteristics. Retrieved from https://www.bls.gov/news.release/pdf/forbrn.pdf

Bushwick S (2011). What causes prejudice against immigrants, and how can it be tamed? Retrieved from: www.scientificamerican.com/article/what-causes-prejudice-aga/

Capozza, D., Trifiletti, E., Vezzali, L., \& Favara, I. (2013). Can intergroup contact improve humanity attributions? International Journal of Psychology, 48(4), 527-541.

Chandler, C. R., \& Tsai, Y. M. (2001). Social factors influencing immigration attitudes: an analysis of data from the General Social Survey. The Social Science Journal, 38(2), 177-188.

Civil Rights Act. (1965). Title VII of the Civil Rights Act of 1964. Retrieved from https://www.eeoc.gov/laws/statutes/titlevii.cfm 
Civil Rights Act. (1991). The Civil Rights Act of 1991. Retrieved from https://www.eeoc.gov/eeoc/history/35th/1990s/civilrights.html

Connor \& Manuel-Krogstad. (2018). Many worldwide oppose more migrations: Both into and out of their countries. Retrieved from https://www.pewresearch.org/fact-tank/2018/12/10/many-worldwideoppose-more-migration-both-into-and-out-of-their-countries/

Cook, S. W. (1978). Interpersonal and attitudinal outcomes in cooperating interracial groups. Journal of Research \& Development in Education, 12, 97-113.

Cote, R. R., \& Erickson, B. H. (2009). Untangling the roots of tolerance: How forms of social capital shape attitudes toward ethnic minorities and immigrants. American Behavioral Scientist, 52(12), 1664-1689.

Derous, E., Nguyen, H. H., \& Ryan, A. M. (2009). Hiring discrimination against Arab minorities: Interactions between prejudice and job characteristics. Human Performance, 22(4), 297-320.

Dhont, K., Roets, A., \& Van Hiel, A. (2011). Opening closed minds: The combined effects of intergroup contact and need for closure on prejudice. Personality and Social Psychology Bulletin, 37(4), 514-528.

Dietz, J. (2010). Introduction to the special issue on employment discrimination against immigrants. Journal of Managerial Psychology, 25(2), 104-112.

Dipboye, R. L., \& Colella, A. (2005). The dilemmas of workplace discrimination. In R. Dipboye \& A. Colella (Eds.), Discrimination at work: The psychological and organizational bases (pp 425462). Mahwah, NJ: Erlbaum.

Dixon, J. C. (2006). The ties that bind and those that don't: Toward reconciling group threat and contact theories of prejudice. Social Forces, 84(4), 2179-2204.

Facchini G., \& Mayda A. M. (2006). Individual attitudes towards immigrants: welfare-state determinants across countries. Working Paper No. 1768, CEPR. Retrieved from https://www.econstor.eu/bitstream/10419/25813/1/517023881.PDF

Feingold, A. (1994). Gender differences in personality: a meta-analysis. Psychological Bulletin, 116(3), 429-456.

Fisher, E.L., Deason, G., Borgida, E. and Oyamot, C.M. (2011). A model of authoritarianism, social norms, and personal values: Implications for Arizona law enforcement and immigration policy. Analyses of Social Issues and Public Policy, 11(1), 285-299.

Foner, N., \& Alba, R. (2008). Immigrant religion in the US and Western Europe: Bridge or barrier to inclusion? International migration review, 42(2), 360-392.

Friedman, G. (2010). The next 100 years: A forecast for the $21^{\text {st }}$ century. New York, NY: Random House.

Gardner, R. C. (1973). Ethnic stereotypes: The traditional approach, a new look. The Canadian Psychologist, 14, 133-148.

Gramlich, J. (2019). How Americans see illegal immigration, the border wall and political compromise. Retrieved from: https://www.pewresearch.org/fact-tank/2019/01/16/how-americans-see-illegalimmigration-the-border-wall-and-political-compromise/

Guimond, S., De Oliveria, P., Kamiesjki, R., and Sidanius, J. (2010). The trouble with assimilation: Social dominance and the emergence of hostility against immigrants. International Journal of Intercultural Relations, 34(6), 642-650.

Ha, S. E. (2010). The consequences of multiracial contexts on public attitudes toward immigration. Political Research Quarterly, 63(1), 29-42.

Hainmueller, J., \& Hiscox, M. J. (2010). Attitudes toward highly skilled and low-skilled immigration: Evidence from a survey experiment. American Political Science Review, 104(1), 61-84.

Hosoda, M., \& Stone-Romero, E. F. (2010). The effects of foreign accents on employment-related decisions. Journal of Managerial Psychology, 25(2), 113-132.

Hughes, M., \& Tuch, S. A. (2003). Gender differences in whites' racial attitudes: Are women's attitude really more favorable? Social Psychology Quarterly, 66, 384-401. 
Huynh, Q. L., Devos, T., \& Smalarz, L. (2011). Perpetual foreigner in one’s own land: Potential implications for identity and psychological adjustment. Journal of Social and Clinical Psychology, 30(2), 133-162.

Jetten J., Mols F., \& Postmes, T. (2015). Relative Deprivation and Relative Wealth Enhances AntiImmigrant Sentiments: The V-Curve Re-Examined. PLoS ONE 10(10): e0139156. Retrieved from https://doi.org/10.1371/journal.pone.0139156

Kelly, P. (2014). Understanding intergenerational social mobility: Filipino youth in Canada. IRPP Study, $45,1-12$.

Kinder, D. R., \& Sears, D. O. (1981). Prejudice and politics: Symbolic racism versus racial threats to the good life. Journal of Personality and Social Psychology, 40(3), 414-431.

Knoll, B. R. (2009). “And who is my neighbor?” Religion and immigration policy attitudes. Journal for the Scientific Study of Religion, 48(2), 313-331.

Krings, F., \& Olivares, J. (2007). At the doorstep to employment: Discrimination against immigrants as a function of applicant ethnicity, job type, and raters' prejudice. International Journal of Psychology, 42(6), 406-417.

Leong, C. H. (2008). A multilevel research framework for the analyses of attitudes toward immigrants. International Journal of Intercultural Relations, 32(2), 115-129.

Lippa, R. A. (2005). Gender, nature, and nurture. Mahwah, NJ: Erlbaum.

McDaniel, E., Nooruddin, I., \& Shortle, A. (2011). Divine boundaries: How religion shapes citizens' attitudes toward immigrants. American Politics Research, 39(1), 205-233.

Miller, N., \& Brewer, M. B. (Eds). (1984). Groups in contact: The psychology of desegregation. Orlando, FL: Academic Press.

Moore, L. M., \& Ovadia, S. (2006). Accounting for spatial variation in tolerance: The effects of education and religion. Social Forces, 84(4), 2205-2222.

Oyamot Jr, C. M., Borgida, E., \& Fisher, E. L. (2006). Can values moderate the attitudes of right-wing authoritarians? Personality and Social Psychology Bulletin, 32(4), 486-500.

Pagotto, L., Voci, A., \& Maculan, V. (2010). The effectiveness of intergroup contact at work: Mediators and moderators of hospital workers' prejudice towards immigrants. Journal of Community \& Applied Social Psychology, 20(4), 317-330.

Pettigrew, T. F., \& Tropp, L. R. (2006). A meta-analytic test of intergroup contact theory. Journal of Personality and Social Psychology, 90(5), 751-783.

Pew Research. (2018). Shifting public views on legal immigration into the U. S. Retrieved from https://www.people-press.org/2018/06/28/shifting-public-views-on-legal-immigration-into-the-uS/

Pratto, F., Sidanius, J., Stallworth, L. M., \& Malle, B. F. (1994). Social dominance orientation: A personality variable predicting social and political attitudes. Journal of Personality and Social Psychology, 67(4), 741-785.

Scheve, K. F., \& Slaughter, M. J. (2001). Labor market competition and individual preferences over immigration policy. Review of Economics and Statistics, 83(1), 133-145.

Smith, H. (1991). The world's religions. New York, NY: HarperCollins Publishers.

Stangor, C. (Ed.). (2000). Stereotypes and prejudice: Essential readings. Philadelphia, PA: Psychology Press.

Stephan, W. G., \& Stephan, C. W. (1985). Intergroup anxiety. Journal of Social Issues, 41(3), 157-175.

Stephan, W. G., Ybarra, O., \& Bachman, G. (1999). Prejudice toward immigrants. Journal of Applied Social Psychology, 29(11), 2221-2237.

Stone, D. L., \& Colella, A. (1996). A model of factors affecting the treatment of disabled individuals in organizations. Academy of Management Review, 21(2), 352-401.

Stone, D. L., Lukaszewski, K. M., Krueger, D. C., \& Canedo, J. C. (2019). Influence of immigrant's attributes on unfair discrimination in organizations. In A. Georgiadou, M. Gonzalez-Perez, and M. Olivas-Lujan (Eds)., Diversity within diversity management: Types of diversity in organizations (pp.79-93). New York: Emerald Publishers. 
Stone, E. F., Stone, D. L., \& Dipboye, R. L. (1992). Stigmas in organizations: Race, handicaps, and physical unattractiveness. In K. Kelley (Ed.), Issues, theory, and research in industrial/organizational psychology (pp 385-457). Oxford: North-Holland.

Tajfel, H., \& Turner, J. C. (1979). An integrative theory of intergroup conflict. In: W. Austin \& S. Worchel (Eds), The social psychology of intergroup relations (pp. 33-47). Monterey, CA: Brooks/Cole.

Timberlake, J. M., \& Williams, R. H. (2012.) Stereotypes of US immigrants from four global regions. Social Science Quarterly, 93(4), 867-890.

Trice, H. M., \& Beyer, J. M. (1993). The cultures of work organizations. New York: Prentice-Hall, Inc.

Vezzali, L., Giovanni, D., \& Capozza, D. (2010). Longitudinal effects of contact on intergroup relations: The role of majority and minority group membership and intergroup emotions. Journal of Community \& Applied Social Psychology, 20, 462-479.

Visintin, E. P., Voci, A., Pagotto, L., \& Hewstone, M. (2017). Direct, extended, and mass-mediated contact with immigrants in Italy: their associations with emotions, prejudice, and humanity perceptions. Journal of Applied Social Psychology, 47(4), 175-194.

Voci, A., \& Hewstone, M. (2003). Intergroup contact and prejudice toward immigrants in Italy: The mediational role of anxiety and the moderational role of group salience. Group Processes \& Intergroup Relations, 6(1), 37-54.

Ward, C., \& Masgoret, A. (2006). An integrative model of attitudes toward immigrants. International Journal of Intercultural Relations, 30(6), 671-682.

Wilkes, R., Guppy, N., \& Farris, L. (2008). "No thanks, we're full": Individual characteristics, national context, and changing attitudes toward immigration. International Migration Review, 42(2), 302329.

Yuker, H. E. (1988). The effects of contact on attitudes toward disabled persons: some empirical eneralizations. In H. E. Yuker (Ed.), Attitudes toward persons with disabilities (pp. 262-274). New York, NY: Springer. 